\title{
Antecedents Affecting Customer's Purchase Intentions towards Green Products
}

\author{
Waseem Akbar \\ Department of Management Sciences, The Islamia University of Bahawalpur, Pakistan
}

Saud Hassan

Department of Management Sciences, The Islamia University of Bahawalpur, Pakistan

Shahroz Khurshid

Department of Management Sciences, The Islamia University of Bahawalpur, Pakistan

Muhammad Niaz

Department of Management Sciences, The Islamia University of Bahawalpur, Pakistan

Muhammad Rizwan (Corresponding author)

Lecturer, Department of Management Sciences,

The Islamia University of Bahawalpur, Pakistan

E-mail: rizwan.arshad@iub.edu.pk

Doi:10.5296/ jsr.v5i1.6566 URL: http://dx.doi.org/10.5296/ jsr.v5i1.6566

\begin{abstract}
Green marketing is a process of producing environment friendly product. Such type of products that are safe from different hazards. Now a days Green marketing is exploring day by day. The eco-friendly products are making by many companies in Globe. Our Purpose of this study is basically to identify that what kind of factors influence the green purchase intentions of consumer of Pakistan. Four preceding factors influence the consumer's purchase intentions based green marketing. By using self-administered questionnaires we collected data from our 160 respondents. For regression analysis we entered all that data into SPSS and do analysis also. Results of our study show significant relationship of green purchase attitude,
\end{abstract}


green perceived value, green trust and ecological knowledge on green purchase intention. These factors influence the green purchase intention. This study is a vital source for the national and international marketers to collect information how different factors effect consumer's purchase intention.

Keywords: Green Marketing, Green purchase intention, Green purchase attitude, Green perceived value, Green trust, Ecological knowledge

\section{Introduction}

The green market is collection of customers that reflect the greenness behavior. In this regard, the green products are those products that are safe for the environment at the usage stage. Green Marketing is a business idea of doing marketing activities in view of customer's fears about protection and preservation of the natural environment. These products are also environment friendly both at the time of production and removal. Green marketing is a process of producing environment friendly product. From last few

Researchers continued to state that the "green market seemed to be actual and growing"

(Menon and Menon, 1997), and "expanding at a amazing rate" (Schlegelmilch et al.,

1996). the public is more willing to purchase green products with sufficient reliable information. The main study of this study is "how to enhance purchase intentions of environmental needs via a green marketing. Now a days consequence, environment came into view as a critical apprehension for business organizations along with governments and societies. According to (Chen, 2010) consumers are keener to purchase green products that are not unsafe to the environment. We must keep in mind these environmental conditions. Green marketing is the only way to help businesses to safeguard environment and livelihood business to survive said Smith (2009).

Environmentalism has occurred to be a dynamic aspect due to increasing issues interrelated to acid rains, and degradation of the land and many more environmental issues depletion of the ozone layer in over the last few decades. A product can deliver worth to customers by offering them benefit and by separating the product from competitors' (Zeithaml, 1988; Aaker, 1996). This resulted in increase in consumer concern with regards to renewal of ecological balance by presenting demands for eco-friendly products in countries around the world. (Ganesan, 1994; Hart and Saunders, 1997) said that trust is a level of the willingness that depend on one object based on the expectation of itsreliability, ability and goodwill.A large number of buyers stated ecological complications as a matter of great importance for them (Diekmann \& Franzen, 1999;Dunlap \& Mertig, 1997).

Over the past eras, the concern about alarming ecological conditions has increased (Chan and Lam., 2002). Kalafatis et al., (1999) said that environmental issues have driven out as a critical substance in market as consumers are now more concerned about wickedest environmental conditions. Green marketing products are getting importance in market, the activities of green marketing are also taking prime importance. According to (Polonsky, 1994) 
the activities of green marketing comprises on offering of green products and services aiming to satisfy customer's needs without distressing environmental concerns of consumers. Now a days environmental concern has become a mainstream issue due to global warming that's why companies have a desire to utilize green opportunities. A sharp rise in green politics has arisen in the Western Europe and US. A encouraging change within consumers' behavior towards eco-friendly related products can be realized due to the increased level of environmental awareness since the 1970s (Alwitt and Pitts, 1996). This change contributed to the start of the green revolution to prevent further damage to the environment.

Attributes, qualities and characteristics of green things are introduced with the help of green marketing and green awareness. So, green marketing and attentiveness for the public that guide them to buy eco-friendly products. This plays an important part to user actual buying intention to buy environmental friendly goods. To fulfill buyer's environmental necessities green advancement includes actions to develop distinctive, rating and promoting goods and services. Green consumers have become a dynamic force behind how companies do business, these ecological customers are creating a new economy around the world. Certainly, the "green consumer" concept was the epicenter of the environmental marketing strategies as well as a key concept, on which prominent marketing academicians and professionals focused. If people have trust in green products so intention makes behaviors of the users. Trust decreasing the perceived risk and so the sale is maximized with creating green intention. Environmental responsibility is also a vital factor. If the society is ecologically liable then they have high green purchase intention. Green marketing has picked up motion due to continuous rise of growing global concern about ecological quality. GPIN means intension to purchase product or services which are not or less harmful for environment. GPIN is the voice of consumers' heart to purchase the environmental friendly products to save the atmosphere. Our this study has independent that how much independent variables impact on dependent variable. For international green marketers Asian consumers have recently become one of the primary targets for the following reasons:

In Asia consumers are increasingly becoming sensible to the alarming ecological problems (Harris, 2006); and in Asia ( $\mathrm{Li}$ and $\mathrm{Su}, 2007$ ) the fast growing economies has led to a dynamic rise of financially-empowered consumers across Asia who are keen to spend more than previous generations.

Our main purpose of this study is to the purchase intention of consumer towards green products that are beneficial for us. Green purchase attitude, trust and perceived value also effect on consumer purchase intention. Trust is main factor because it is the faith and benevolence of customer. The main variable in our research area is Green Purchase Intention. The other variables that are linked to GPI are; Green perceived value, Green purchase attitude, Eco knowledge, Green trust and Socio-demographic variables (age, gender, income, education. The purpose of the study is to check the influence of independent variables on dependent variable. GPI is basically the purchase intention of customer towards green products. If they trust on green products and have knowledge about green products and environment and his income is sufficient to purchase these green products. Mostly women are attracting towards green products. 


\section{Literature Review}

\section{Green Purchase Intention}

Intentions defined as consumer's specific purpose in performing an action or series. Green purchase intention (GPI) is simply defined as an intention of a customer to buy a product which is less or not unsafe for the society and environment. We can also say it is an internal desire and willingness of the people to buy a fewer harmful and eco-friendly product. It is describe by the consumer's cautious selection of the products that are environmentally beneficial. In this study we also said that GPI is an individual's intention to consumption the products that are not harmful for the environment and humanity. According to (Chen, 2011)the pollution and other environmental issues that are being produced, the society and public are taking more seriously noticed about such issues. Green purchase intention significantly influences the green purchase behavior. People are much conscious about the environmental problems, many customers have environmental beliefs and they are willing to purchase green products that have less harmful impact on the environment (Peattie, 1995).

To achieve the consumer's environmental beliefs the marketers and manufacturers needed to change their manufacturing and business models (Chen, 2010; Rizwan et al., 2013). GPI mentions the eagerness expressed by the consumer to act for the benefit of the environment. If buyers have had a trust experience with the seller, they would possess a higher level of purchase intentions. By the analysis of previous studies we easily determined that there is a developing trend in the people to use such products that are less harmful for the environment. Even they are willing to pay more for such products, which have less effect on the environment. If consumers perceive that the value of a product is higher, they are more likely to purchase the product.

\section{Green Purchase Attitude}

Attitude is a person's increasingly satisfactory or unsatisfactory valuations, trends and feelings toward an object or intimation Armstrong and Kotler (2009). According to Eagly and Chicken (1995) with some degree of favor or disfavor attitudes is a psychological trend that is expressed by evaluating a particular object. Chen (2009) trusts that ecological attitudes governs a person's attitude on the way to organic foods and if a person is govern to become better, he or she will shows a positive attitude. Swait and Sweeney (2000) stated that perceived value associated with customer attitude. The attitudes are predilections to respond leads towards actual consumer behavior.

Philosophy of Rational Action states that consumer attitude influences the consumer purchase behavior (Ajzen and Fishbein, 1980). Marketing practitioners along with academicians struggle to investigate attitudes of consumers for green products and their needs for green product (D'Souza et al., 2005; Rizwan et al., 2013). The research has explained the relation of intention, attitude and behavior which shows that actions of people are in accordance with their intentions (Ajzen, 1985, 1988; Ajzen and Fishbein, 1980). Usually the positive attitude, the stronger the intention to perform a behavior and vice versa.

H1: Green purchase attitude is positively associated Green purchase intention 


\section{Green Perceived Value}

Green perceived value (GPV) means the total features, benefits and performance of a Green product in the mind of customer. GPV is a customer valuation about his overall benefit from Green product Spreng and Patterson (1997) and Drew and Bolton (1991). We can also be defined as "An overall assessment by a consumer to get the net benefit of a product or service between what is received and what is given based on the consumer's environmental desires, keeping judgments, and needs to make a product eco-friendly" (Spreng and Patterson 1997).Simply it is the imagination of the customer that what he can consequent from a green product.. A product's greenness is not the guarantee of its sale. According to (Sweeney et al.1999) GPV has been already explored, it has a positive impact on marketing performance. The GPV is very important today because different companies are improving GPIN by emphasizing their product value (Steenkamp and Geyskens, 2006). GPV is not playing an important role in affecting GPIN but it also has an essential factor in maintaining long term customer relationship (Zhuang et al. 2010; Zeithaml, 1988).

The effect of green perceive value and green purchase intention is positive Perceive value is a set of attributes which are related to the perception of a product's value, so it can build up a positive word-of-mouth effect and raise purchase intentions. According to Chang and Chen (2008) if consumers perceive that the value of a product is higher, they are more likely to purchase the product. Moreover, perceived value has significant effects on consumers' trust (Kim et al., 2008).Past research results show that there is a positive relationship between green perceive value and green purchase intention. Purchase intention is much influenced by the green value of the product. Green perceived value is considered very important to green purchase intentions, so from this study, we suggest the following hypothesis.

H2: Green perceived value is positively associated with green purchase intentions.

\section{Green Trust}

Trust affected from four things, integrity, goodwill, beliefs and ability. It is an anticipation held by one party that the word, promise, or statement of another party (Rotter, 1971; Schurr and Ozanne, 1985). As well according to (Hart and Saunders, 1997) trust is a level of the assurance that another party would behave as expected. We also said that customer trust is a vital factor of long-term consumer behavior (Lee et al., 2011).

Consumer purchase intentions are affected by consumer trust (Harris and Goode, 2010). Past literature theorizes that customer trust is a factor of consumer purchase intentions (Schlosser et al., 2006). GPT would affect consumer's purchase behaviors in the environmental era Chen (2010). Thus, buyer trust is an antecedent of customer purchase intentions (van der Heijdenet al., 2003). Customer trust would positively influence customer purchase intentions (Schlosser et al., 2006) earlier research shows. Recently some companies exaggerate the green performance of their products, and thereby customers are reluctant to trust them any more (Kalafatis and Pollard, 1999). Thus, Chen (2010) says that green trust would impact on consumer's purchase behaviors to buy green products. Past literature recommends that GPT is a determinant of GPIN (Schlosser et al. 2006). If buyers have had a good experience with 
the seller, they would have a higher level of GPIN. Recently, customers are unwilling to trust on few companies due to overemphasizing the environmental performance of their product (Kalafatis and Pollard, 1999). So this study of hypothesis shows that green trust has positive influence on purchase intention.

H3: Green trust is positively associated with green purchase intentions

\section{Ecological Knowledge}

Eco knowledge is knowledge about environment and its concern. Basic knowledge about environment like basic needs also included. (e.g. Hoch and Deighton,1989; Horton and Turnage, 1976;) says that the behavioural literature in general advocates a positive association between knowledge and behavior that ecological knowledge has little approach on the performance of ecologically acts. On the other hand, Eco knowledge (EC) means to have the knowledge about the effects of a product on environment. When the people evaluate a product and its features and benefits in the context of environment, it is called EC. A person, who will have more knowledge about product and its performance, will be more intend to purchase it. It is in the case of green purchase intention.

In the context of environmental management, this study hypothesizes that eco knowledge of customers positively affects their green purchase intentions and proposes the following hypothesis:

H4: Ecological knowledge has positive/direct effect on GPI.

\section{Research Methodology}

The current research is descriptive in its nature. Descriptive research can be explained as describing something, some occurrence or any particular situation. Descriptive researches are those researches that describe the existing situation instead of interpreting and making judgments (Creswell, 1994). The main objective of the descriptive research is verification of the developed hypothesis that reflects the current situation. This type of research provides information about the current scenario and focus on past or present for example quality of life in a community or customer attitudes towards any marketing activities (Kumar, 2005).

\subsection{Sample Data}

In order to collect the data for understanding the situation about the purchase intentions of green products, a sample of 160 respondents were asked to participate in a self-administered questionnaire. The population for the current research is consumer in Pakistan. The current study exploits a nonprobability sampling technique that is ease sampling. Convenience sampling is a sampling technique that obtains and collects the relevant information from the sample or the unit of the study that are conveniently available (Zikmund, 1997). Convenience sampling is normally used for collecting a large number of completed surveys speedily and with economy (Lym et al, 2010). 


\section{Macrothink}

Journal of Sociological Research

ISSN 1948-5468

2014, Vol. 5, No. 1

It is ensured that the sample members possess two main qualifications to participate in the self-administered survey. First, the sample members should have enough knowledge about green marketing; secondly, they have a regular purchasing pattern of buying some green products, it definitely influences the attitude and behavior of the respondent.

\subsection{Instruments and Measures}

The survey instrument of the current study address two major purposes: First is to analyze the relationship of different variables in the adoption of green marketing. Second, to collect information about the different characteristics of the respondents that can be used to understand the variations in different categories.

The survey instrument contains two sections. Section 1 includes different personae and demographic variables. This section will obtain the respondent's information about gender, age, income and education.

Section 2 includes the latent variables that are important in the current study. These variables include green purchase intention, green purchase attitude, green perceived value, green perceived trust and ecological knowledge. This section of study is developed based on the past literature and already used questionnaires. The scales of the study were adopted from the previous literature and published studies. The first variable of the study was Green purchase intention having four items taken from Chang and Chen (2008). The next variable is Green perceived Trust having five items that was taken from the study of Chen (2010). The next variable Green perceived Value refers to Patterson and Spreng (1997). The next variable Green purchase Attitude refers to Armstrong and Kotler (2009), attitude is a person's steadily satisfactory or unsatisfactory assessments. Eco knowledge variable refers to (e.g. Hoch and Deighton 1989. 
Table 1: Scales of the Study

\begin{tabular}{|c|c|c|c|}
\hline No & Variable & Items & References \\
\hline 1. & $\begin{array}{l}\text { Green } \\
\text { Purchase } \\
\text { Intention }\end{array}$ & $\begin{array}{l}\text { 1. I would intend to buy green products. } \\
\text { 2. My willingness to buy green products is } \\
\text { high. } \\
\text { 3. I am likely to purchase any green } \\
\text { product. } \\
\text { 4. I have a high intention to buy green } \\
\text { product. }\end{array}$ & $\begin{array}{l}\text { Bolton, R.N. and } \\
\text { Drew, } \\
\text { (1991), }\end{array}$ \\
\hline 2. & $\begin{array}{l}\text { Green } \\
\text { Purchase } \\
\text { Attitude }\end{array}$ & $\begin{array}{l}\text { 1. Green practice is good. } \\
\text { 2. Green practice is useful. } \\
\text { 3. Green practice is rewarding. } \\
\text { 4. Green practice is sensible. } \\
\text { 5. Green practice is responsible. }\end{array}$ & $\begin{array}{l}\text { Swait and } \\
\text { Sweeney (2000) }\end{array}$ \\
\hline 3. & $\begin{array}{l}\text { Green } \\
\text { Perceived } \\
\text { Value }\end{array}$ & $\begin{array}{l}\text { 1. Green product's environmental } \\
\text { functions provide very good value for } \\
\text { you. } \\
\text { 2. Green product's environmental } \\
\text { performance meets your expectations. } \\
\text { 3. Your purchase to green products because } \\
\text { they have more environmental concern } \\
\text { than other products. } \\
\text { 4. Your purchase to green products because } \\
\text { they have environmental friendly. } \\
\text { 5. Your purchase to green products because } \\
\text { they have more environmental benefits } \\
\text { than other products. }\end{array}$ & $\begin{array}{l}\text { Chaudhuri, } \\
\text { (1997), }\end{array}$ \\
\hline
\end{tabular}




\begin{tabular}{|c|c|c|c|}
\hline 4. & $\begin{array}{l}\text { Green } \\
\text { Perceived } \\
\text { Trust }\end{array}$ & $\begin{array}{l}\text { 1. You feel that green product's } \\
\text { environmental reputation is generally } \\
\text { reliable. } \\
\text { 2. You feel that green product's } \\
\text { environmental performance is generally } \\
\text { reliable. } \\
\text { 3. You feel that green product's } \\
\text { environmental claims are generally } \\
\text { trustworthy. } \\
\text { 4. Green product's environmental concern } \\
\text { meets your expectations. } \\
\text { 5. Green product's keep promises and } \\
\text { commitments for environmental } \\
\text { protection. }\end{array}$ & $\begin{array}{l}\text { Chen, } \\
\text { (2008a), }\end{array}$ \\
\hline 5. & $\begin{array}{l}\text { Ecological } \\
\text { Knowledge }\end{array}$ & $\begin{array}{l}\text { 1. It is necessary to have knowledge about } \\
\text { environment. } \\
\text { 2. Ecological knowledge has influence on } \\
\text { green } \\
\text { 3. This knowledge of product is an } \\
\text { effective way about green products. } \\
\text { 4. Consumers with higher eco knowledge } \\
\text { have higher green purchase intention. }\end{array}$ & $\begin{array}{l}\text { Arbuthnot and } \\
\text { Lingg }(1975\end{array}$ \\
\hline
\end{tabular}

\subsection{Procedure}

The questionnaire was distributed among 160 respondents in Bahawalpur city of Pakistan. These respondents are selected based on the criteria above mentioned. Before giving the questionnaire, the purpose of the study and questions were explained to the respondents so they can easily fill the questionnaire with relevant responses. A total of 160 questionnaires selected. After collecting, the completed questionnaires were coded and entered into SPSS sheet for further analysis.

\subsection{Reliability Analysis}

Overall Cronbach's alpha of Green Marketing questionnaire items were 0.890 that is more than acceptable. This shows that all the 23 items were reliable and valid to measure the opinions of consumers towards Green Marketing.

\section{Table 2: Reliability of Measurements Instrument}




\begin{tabular}{|l|l|l|}
\hline Scales & Items & Croubach Alpha \\
\hline Green Purchase Intention & 4 & 0.743 \\
\hline Green Purchase Attitude & 5 & 0.738 \\
\hline Green Perceived value & 5 & 0.667 \\
\hline Green Perceived Trust & 5 & 0.637 \\
\hline Ecological Knowledge & 4 & 0.641 \\
\hline
\end{tabular}

\section{Results And Analysis}

\subsection{Profile of the Respondents}

Personal and demographic information of the respondents is presented in the following table.

Table 3:

\begin{tabular}{|c|c|c|c|}
\hline Variable & Category & Frequency & Percentage \\
\hline \multirow{2}{*}{ Gender } & Male & 73 & 46 \\
\hline & Female & 87 & 54 \\
\hline \multirow{6}{*}{ Age } & $15-20$ years & 20 & 13 \\
\hline & 20-25 years & 87 & 54 \\
\hline & $25-30$ years & 40 & 25 \\
\hline & $30-35$ years & 8 & 5 \\
\hline & $35-40$ years & 2 & 1 \\
\hline & Above 40 years & 3 & 2 \\
\hline \multirow{3}{*}{ Income } & Below 15000 & 50 & 31 \\
\hline & $15000-25000$ & 40 & 25 \\
\hline & $25000-35000$ & 35 & 22 \\
\hline
\end{tabular}




\begin{tabular}{|l|l|l|l|}
\hline \multirow{5}{*}{} & $35000-45000$ & 12 & 8 \\
\cline { 2 - 5 } & $45000-55000$ & 5 & 3 \\
\cline { 2 - 4 } Education & Above 55000 & 18 & 11 \\
\hline \multirow{5}{*}{} & Matriculation & - & - \\
\cline { 2 - 5 } & Inter & 10 & 6 \\
\cline { 2 - 4 } & Bachelor & 67 & 42 \\
\cline { 2 - 4 } & Master & 70 & 44 \\
\cline { 2 - 4 } & MS/M.Phill & 12 & 1 \\
\cline { 2 - 4 } & PHD & 1 & 8 \\
\hline
\end{tabular}

\subsection{Hypothesis Testing}

This section of the study finally tests the model after satisfying the requirements of reliability and validity. The casual relationships of the independent variable were measured on dependent variables.

\subsubsection{Green Purchase Attitude and Green Purchase Intention}

According to the results of this study, The variable of Green purchase attitude has a significant positive relationship with green purchase intention. Specifically, this variable has a significant positive relationship with $($ Beta $=.587)$ and $(\mathrm{p}<0.01)$. That means the Green purchase attitude more than $50 \%$ to green purchase intention. Results of the current study validate the $\mathrm{H} 1$.

\subsubsection{Green Perceived Value and Green Purchase Intention}

The regression results of the study confirm the significant positive relationship between Green perceived value and Green purchase intention with (Beta=.140) and $(p<0.01)$. According to these results, Green perceived value contributes more than $14 \%$ to Green purchase intention. This result of study validates $\mathrm{H} 2$.

\subsubsection{Green Perceived Trust and Green Purchase Intention}

Regression analysis of the green marketing model shows that there is a significant positive relationship with $(B e t a=.130)$ and $(\mathrm{p}<0.01)$. The results suggest that Green perceived trust almost $13 \%$ more than Green purchase intention. The result of the study support H3. 


\subsubsection{Ecological Knowledge and Green Purchase Intention}

The regression results of the study confirm the significant positive relationship between Ecological Knowledge and Green purchase intention with (Beta=.105) and $(\mathrm{p}<0.01)$. According to these results, Eco knowledge is $10 \%$ more than Green purchase intention. The result of the study support $\mathrm{H} 4$.

Table 4: Regression Results

\begin{tabular}{|l|l|l|l|l|l|l|}
\hline $\begin{array}{l}\text { Hypothesi } \\
\text { S }\end{array}$ & Model Variables & Estimate & S.E & C.R & P & Results \\
\hline H1 & $\begin{array}{l}\text { GPA } \\
\text { GPI }\end{array}$ & 0.587 & 0.095 & 7.047 & 0.000 & supported \\
\hline H2 & $\begin{array}{l}\text { GPV } \\
\text { GPI }\end{array}$ & 0.140 & 0.102 & 0.445 & 0.007 & supported \\
\hline H3 & $\begin{array}{l}\text { GPT } \\
\text { GPI }\end{array}$ & 0.130 & 0.105 & 1.174 & 0.012 & supported \\
\hline H4 & $\begin{array}{l}\text { EK } \\
\text { GPI }\end{array}$ & 0.105 & 0.091 & 0.075 & 0.075 & supported \\
\hline
\end{tabular}
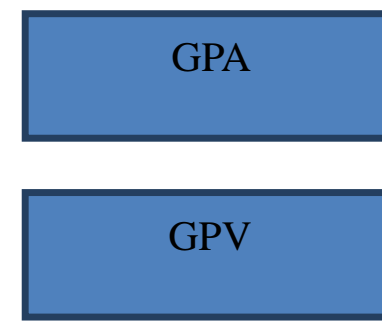

$\mathrm{H} 1(\beta=0.587)$

$\mathrm{H} 2(\beta=0.140)$
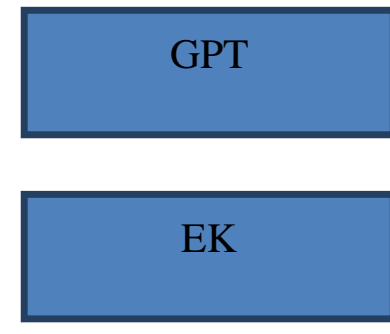

$\mathrm{H} 3(\beta=0.130)$

$\mathrm{H} 4(\beta=0.105)$ 


\section{Figure: Structural Model Results}

\section{Discussion}

This study provides an approach about GPI, GPA, GPV.GPT and EK to start the building process of purchase intentions in the background of environmental management. This study develops a research framework of green purchase intentions to further analyze its associations with GPV, GPA, GPT and EK. The experiential outcomes show that GPV positively relates to GPIN. This study has five major academic contributions. First, this study makes a new research framework of GPIN by combining the two concepts relationship marketing and green marketing. The second contribution is that when the consumers are forced in compromising on product's features and product's greenness, they are not ready to sacrifice their needs and requirement for the sake of greenness and environment. This study develops a research framework that explain this issue by studying the different concepts, the product greenness, product perceived value and product purchase attitude to increase people's purchase intentions of ecological needs under the context of customer uncertainty. Third, this study shows that the relationship between GPIN and its two independent variables GPV and GPA, GPT is discussed as another variable among EK and GPIN. Fourth, this study explains the research of Perceived value and purchase intention in the context of green marketing. In this study we discuss about the intentions of consumers about green products. Green purchase intention is basically the choice of a buyer about green products. This study tells us about positive effect of intention about green products. Buyer's behavior affects the buyer's attitude. In this study attitude will be theorized as a single aspect. GPI refers to the willingness stated by the consumer to act for the benefit of the environment Green purchase attitude has a direct and positive influence on consumers green purchase intention. Green perceived value is basically the performance and assistance of a product in customer's mind. Now a days many companies are improving their values and working on green marketing. Green perceived value has direct effect on purchase intention. We mostly rely on perceived value and trust of green consumers. Green trust is also an important factor in green marketing and it has a direct effect on green purchase intention. Trust is basically begun from belief, honesty, generosity and skill. Consumer trust is an antecedent of customer purchase intentions. These are the important factor that directly effect on purchase intention on customers. Past literature theorizes that customer trust is a element of consumer purchase intentions. GPIN is characterizes as "the probability that a consumer would buy a particular product ensuing from his or her environmental needs". In the framework of environmental management, this study assumes that green trust of customers positively marks their green purchase intentions. We often collect the data from males and females also. Customer trust positively affects customer purchase intentions. In the context of environmental management, this study theorizes that green trust of customers positively touches their green purchase intentions. We notice that females are most conscious about their purchase that's why they prefer green products. One thing more 25-35 years person are focus on Green products. Green products are good for customers. The research has described the relation of intention, attitude and behavior which shows that actions of people are in accordance with their intentions. .Eco knowledge is a knowledge about environment and it's concern. Basic knowledge regarding environment like 
basic needs also included. Ecological knowledge has little attitude on the act of environmentally friendly. Eco knowledge (EC) means to have the knowledge about the possessions of a product on environment. When the people assess a product and its features and benefits in the framework of environment, it is called EC. A person, who will have more knowledge about product and its performance, will be more propose to purchase it. It is in the case of green purchase intention. So, eco knowledge has a good impact on green marketing because it is totally about our environmentally friendly products. If consumers perceive that the value of a product is higher, they are more likely to purchase the product. A helpful starting point for marketers is to make strategies for raising perceptions of green value and for serving latent customers to develop enough green trust to build up a long lasting relationship in the environmental era. So, our whole study is basically the theoretical frame work. We study also previous papers and that papers help in collecting information. Green Marketing is exploring day by day. Many companies are focusing on this and launching their products. For example Toyota hybrid pyres car is a good example of green marketing.

\section{Limitations and Future Research}

It is important to note that due to limited resources, the existing study is limited to one city of Pakistan and it could not be the demonstrative of the all citizens of Pakistan. Present study includes the very small sample size; the follow up researches may increase the sample size and can collect the data from various major cities of Pakistan like Lahore, Karachi and Islamabad. Useful sampling is used and the respondent are all from the same university as such result may not represent the intention of whole country, it can limit the likely of the conclusions. In this respect further research is clearly needed in order to enhance the understanding of green marketing and green purchase intention of consumer towards ecofriendly products.

\section{REFERENCES}

Menon A, Menon A. 1997. Enviropreneurial marketing strategy: the emergence of corporate environmentalism as market strategy. Journal of Marketing 61, 51-67.

Schlegelmilch, B.B., Bohlen, G.M. and Diamantopoulos, A. (1996).The link between greenpurchasing decisions and measures of environmental consciousness.European Journal of Marketing, 30(5), 35-55.

Diekmann, Andreas, and Axel Franzen (1999), "The Wealth of Nations and Environmental Concern”, Environment and Behavior 31, 540- 49.

Dunlap, Riley E., and Angela G. Mertig (1997), "Global Environmental Concern: An Anomaly for Postmaterialism”. Social Science Quarterly 78, 24-29.

Kalafatis, S. P., Pollard, M., East, R., \&Tsogas, M. H. (1999). Green marketing and Ajzen's

Theory of Planned Behaviour: A cross-market examination. Journal of ConsumerMarketing, $16(5), 441-460$. 


\section{I Macrothink}

Journal of Sociological Research

ISSN 1948-5468

2014, Vol. 5, No. 1

Chen, Y.-S. (2010), “The drivers of green brand equity: green brand image, green satisfaction, andgreen trust".Journal of Business Ethics, 93(2), 307-19.

Chen, Y.-S. (2011) “Green organizational identity: sources and consequence".Management Decision, 49(3), 384-404.

Peattie, K. (1995) Environmental Marketing Management: Meeting the Green Challenge. London: Pitman Publishing.

Chen, Y.-S. (2010) "The drivers of green brand equity: green brand image, green satisfaction, and green trust", Journal of Business Ethics, 93(2), 307-319.

Kumar, P. D. (December 2010) "Green Marketing: A Start to Environmental Safety."Advances in Management, 4(12), 59-61.

Ajzen, I. and Fishbein, M. (1980). Understanding Attitudes and Predicting Social Behavior.Englewood Cliffs. New Jersey. Prentice Hall.

Sweeney, J.C. and Soutar, G.N. (2001), "Consumer perceived value: the development of amultiple item scale".Journal of Retailing, 77(2), 203-20.

D’Souza, C., Taghian, M. \& Lamb, P. Public environmental consumerism: Recycling behaviorand its impact on intentions to purchase green products. Proceedings of the $30^{\text {th }}$ Annual Macromarketing Conference.2005, 28-May31, St Petersburg, Florida.

Bolton, R.N. and Drew, J.H. (1991), "A multistage model of consumers' assessment of service quality and value."Journal of Consumer Research, 17(4), 375-84.

Sweeney, J.C., Soutar, G.N. and Johnson, L.W. (1999), "The role of perceived risk in thequality-value relationship: a study in a retail environment."Journal of Retailing, 75(1),77-105.

Steenkamp, J.B.E.M. and Geyskens, I. (2006), "How country characteristics affect the perceivedvalue of web sites."Journal of Marketing, 70(3), 136-50.

Zeithaml, V.A. (1988), "Consumer perceptions of price, quality, and value: a means-end modeland synthesis of evidence".Journal of Marketing, 52(3), 2-22.

Zhuang, W., Cumiskey, K.J., Xiao, Q. and Alford, B.L. (2010), “The impact of perceived value onbehavior intention: an empirical study."Journal of Global Business Management, $6(2), 1-7$.

Chen, Y.-S.(2008a), "The driver of green innovation and green image - green corecompetence."Journal of Business Ethics, 81(3), 531-43

Kim, C., Zhao, W. and Yang, K.H. (2008), "An empirical study on the integrated frameworkofe-CRM in online shopping: evaluating the relationships among perceived value, satisfaction, and trust based on customers' perspectives." Journal of Electronic Commerce in Organizations, 6(3), 1-19.

Rotter, J.B. (1971), “Generalized expectancies for interpersonal trust.”American 
Psychologist,26(5), 443-450.

Rizwan, M., Khan, A, A., Misbah, K. A., Nawaz, I., Tahir, S., Siddique, A. and Gillani, S. N.

A. (2013). Measuring the Scope of Green Products in Developing Countries: A Myth Breaking Study, American Journal of Scientific Research, 85, 32-46

Schurr, P.H. and Ozanne, J.L. (1985), "Influences on exchange processes: buyers' preconceptionsof a seller's trustworthiness and bargaining toughness."Journal of Consumer Research,11(4), 939-953.

Hart, P. and Saunders, C. (1997), "Power and trust: critical factors in the adoption and use ofelectronic data interchange.”Organizational Science, Vol. 8(1), 23-42.

Lee, J., Park, D.-H. and Han, I. (2011), “The different effects of online consumer reviews onconsumers' purchase intentions depending on trust in online shopping malls: anadvertising perspective."Internet Research, 21(2), 187-206.

Harris, L.C. and Goode, M.M.H. (2010), "Online servicescapes, trust, and purchase intentions."Journal of Services Marketing, 24(3), 230-43.

Schlosser, A.E., White, T.B. and Lloyd, S.M. (2006), "Converting web site visitors into buyers:how web site investment increases consumer trusting beliefs and online purchaseintentions."Journal of Marketing, 70(2), 133-48.

Van der Heijden, H., Verhagen, T. and Creemers, M. (2003), "Understanding online purchaseintentions: contributions from technology and trust perspectives."European Journal ofInformation Systems, 12(1), 41-48.

Kalafatis, S.P. and Pollard, M. (1999), “Green marketing and Ajzen's theory of planned behaviour:a cross-market examination."Journal of Consumer Marketing, 16(4/5), 441-60.

Hoch, S.J. and Deighton, J. (1989), "Managing what consumers learn from experience."Journal of Marketing, 53(April),1-20.

Horton, D, and Turnage, T. (1976).Human Learning. Englewood Cliffs, NJ: Prentice-Hall.

Zeithaml, V.A. (1988), "Consumer perceptions of price, quality, and value: a means-endmodelSand synthesis of evidence.” Journal of Marketing, 52(3), 2-22.

Kumar (2005:179) motivates that purposive sampling is extremely usefulwhen constructing a historical reality, describing a phenomenon ordeveloping something about which only a little is known.

Rizwan, M., Asif, R. M., Hussain, S., Asghar, M., Hassan, M. \& Javeed, U. (2013) Future of

Green Products in Pakistan: An Empirical Study about Green Purchase Intentions, Asian Journal of Empirical Research, 3(2), 191-207

Creswell, J.W. (1994).Research Design: Qualitative and Quantitative Approaches.Thousand Oaks. London: SAGE. 
Zikmund, W. G. (1997). Business Research Method.(5 ${ }^{\text {th }}$ d.). The Drydenpress, Harcourt Brace College Publishers, Orlando, Florida. 